\title{
From Ararajuba to Ornithology Research: an historical overview of bird journals published by the Brazilian Ornithological Society
}

\author{
Leandro Bugoni $^{1}$ (D) \\ Published online: 18 June 2020 \\ (C) Sociedade Brasileira de Ornitologia 2020
}

The recently launched Ornithology Research (ISSN 2662$673 \mathrm{X}$ ), owned by the Brazilian Ornithological Society and co-published by Springer Nature, is a "new" journal dedicated to general bird biology, focused, but not exclusively, on the biodiversity-rich Neotropical region. However, it is not a justhatched outlet for ornithologists. With an about 30-year-old history, thousands of pages published in 78 issues, under other names, formats, and scope, it has a solid history, now a leading bird journal in the Neotropics. This editorial aims to unbury and describe this trajectory to our ever supporting readers and authors, as well as the new global-wide audience.

The Brazilian Society of Ornithology (Sociedade Brasileira de Ornitologia), formally founded in 1987 (Höfling et al. 2017), had early established its intention to launch an ornithological journal dedicated to Neotropical birds. The first issue of Ararajuba (ISSN 0103-5657), the common name of the endemic golden parakeet (Guaruba guarouba) showing the green and yellow colors of the Brazilian flag, edited by Dr. Luiz P. Gonzaga, had the first issue published in 1990. In its 124 pages, icons of the Neotropical ornithology such as J. Vielliard, E.O. Willis, H. Sick, and D.C. Oren authored 20 full papers and notes, which included the description of the Cipó Canastero, Asthenes luizae (Vielliard 1990). Up to 1995, and despite some temporal gaps, it was published as a single issue annually, predominantly in Portuguese, but accepting manuscripts in English and Spanish. In times of snail-mail communication among authors, the editor, and reviewers, many of which in North America and Europe, building a solid and regular journal had been a remarkable feat. Since 1996, under the guidance of Dr. Miguel Â. Marini as Editor-in-chief, Ararajuba started publishing two issues per year, which lasted up to vol. 13, in 2005, with Editors-in-chief Drs. Regina H. F. Macedo, Luiz

Leandro Bugoni

lbugoni@yahoo.com.br

1 Universidade Federal do Rio Grande - FURG, Waterbirds and Sea Turtles Lab, Instituto de Ciências Biológicas, Rio Grande, RS, Brazil dos Anjos, and Augusto Piratelli during this period. At this phase, the journal associated with the recently created Brazilian Ornithological Records Committee (CBRO) from vol. 10 (2002) onwards, for publication of taxonomic and nomenclatural notes, is substitution to the ephemeral Nattereria journal published by the Committee, as well as records or documentation of species new to the country.

Since the second issue of 2005, under the leadership of the Editor-in-chief Dr. Marco A. Pizo, and after an extensive discussion by the Society members in successive meetings at the Brazilian Ornithological Congresses, it changed to be a quarterly released journal, under the name Revista Brasileira de Ornitologia (ISSN 2178-7875, online version). Also, in 2005 occurred the only major change of the cover in 30 years from the traditional white-and-green hand-painted Golden Parakeet made by Carlos Yamashita to a diversity of color pictures and drawings. The periodicity and name remained as such until 2019. During the 2000s, important changes included the discontinuity of the printed version (vol. 15, 2007, already under guidance of Dr. Luis F. Silveira), which alleviated printing costs and traditional mail to libraries and Society members. Due to nomenclatural and taxonomical issues, printed copies were still sent along the following years to a few museums in Brazil (Museu de Zoologia da Universidade de São PauloMZUSP, Museu Nacional do Rio de Janeiro-MNRJ), as well as abroad (American Museum of Natural HistoryNew York, Smithsonian Institution-Washington D.C., and British Museum of Natural History-Tring). A range of special issues, including one on bird genetics (vol. 14, issue 1), another on raptors (14, issue 4), two others on shorebirds and seabirds-vols. 18(3) and 19(4)-on the Amazonian rainforest birds (19, issue 2$)$, all with invited editors, consolidated the maturity of the journal. Indexing had been a key aspect, given visibility and formal acceptance internationally.

However, it still had pressure for more visibility and impact. Thus, the decision to publish an English-only journal lasted a while from the predominantly Portuguese, up to 2011, to truly implementation in 2014 (vol. 22). The transition to fully English occurred under guidance of Dr. Alexandre 
Aleixo as the Editor-in-chief. Despite this decision had been taken previously, Revista Brasileira de Ornitologia still had under review manuscripts written in Portuguese, which were finally published in following issues. This procedure launched it as a truly international journal, despite it retained its name in Portuguese, due to concerns on indexing and impact factor. At this time, it already had impact factor scored by Journal of Citation Reports (IF $=0.134$ in 2011, the first year measured). The launching of a system for manuscript submission, review and publication truly online, switched the previous procedure, by email, all kindly hosted at the Museu Paraense Emílio Goeldi. Apex during this phase had been special issues on the birds of the Caatinga dry forest Biome (vol. 20, issue 3), another honoring J. Mazar-Barnett (vol. 22, issue 2) and the first release of the commented Brazilian bird checklist, by CBRO in 2015 (vol. 23, issue 2). The publication of a special issue of the Ornithological Congress of the Americas held in Iguazu, Argentina (vol. 26, issue 2), with Dr. Leandro Bugoni as Editor-in-chief was also a special landmark. During this period, indexing was no longer a problem, and impact factor had been consolidated, up to IF $=0.565$ in 2017. Such aspects were a concern by authors in Brazil, and probably elsewhere, as they have implications on the journal ranking on the evaluation process of graduate programs by the Brazilian federal agency, CAPES (Foundation for Higher Education Development in Brazil). Nearly regular publication of scheduled issues, indexing, and impact factor were no guarantee of performance in the ranking system. As an unfortunate outcome, pressure on graduate students and supervisors had led to a search for better-ranked journals. Because rejection rate remained constant along the years, about 40 to $60 \%$, the number of accepted papers had reduced, despite substantial between-year variation (Fig. 1). Not surprisingly, decrease in submission occurred, which lit alert lights.

\section{The history in numbers and the path forward}

Ararajuba and Revista Brasileira de Ornitologia had a long, proud history, built by tenacious authors, reviewers, and editors: 78 issues, about 7600 pages, and 1090 published pieces (full papers, notes, and a few book reviews and obituaries; Fig. 1). It presented about a dozen of new species to science, such as A. luizae (Vielliard 1990), Antilophia bokermanni (Coelho and Silva 1998), Glaucidium mooreorum (Silva et al. 2002), Scytalopus pachecoi (Mauricio 2005), S. diamantinensis (Bornschein et al. 2007), S. petrophilus (Whitney et al. 2010), and Formicivora paludicola (Buzzetti et al. 2013), as well as the described but already extinct Cichlocolaptes mazarbarnetti (Mazzar-Barnett and Buzzetti 2014). A total of $\sim 3200$ authors and coauthors were benefited, many several times, as well as it provided strong support to conservation practices in their pages. All these had not been possible without efforts of the abovementioned editors-in-chief, dozens of subject editors, over 2000 reviewers, many of which several times, authors, countless readers in many countries, and the unconditional and continued support from successive boards of directors of the Society. None editorial or society board members, as well as reviewers, received any payment to carry out such qualified, but sometimes instinctive work. Publication had been open access and no charge to authors occurred in any phase. Funds for printing, page design, and sometimes copy-editing by professionals had been gathered from public governmental calls by CNPq (National Scientific and Technological Development Council), CAPES, and more eventually from private and public companies (e.g., Petrobras), as well as NGOs (e.g., Fundação O Boticário). In those periods when funds were lacking, the Society covered costs. We are deeply in debt with all people and institutions which made possible this successful journey.

But it is time to refresh interest and make the journal, from submission to production and diffusion even more professional and updated to new times and technologies. The incongruence of publishing an entirely English journal with a name still in Portuguese had been tackled. The partnership with Springer Nature and with the review process through Editorial Manager had reached us in good time. We now have much broader visibility through Springer Nature platforms, commercialization all across the globe, through individual or institutional subscriptions. Open access had been maintained as an option, with Open Choice, for authors and their institutions, in line with current trends globally, and Society members will have access to the articles, as usual. Editorial independency over the content had been maintained, which guarantee an unbiased review process. Manuscript production after acceptance is receiving professional attention, and papers should be released, in digital format only, as soon as proofs had been corrected, speeding up the process from final decision to paper availability online. In addition, 257 papers since the English-only phase, i.e., from vol. 22 (2014) to 27(2019), are available under Open Access in the journal webpage https://link. springer.com/journal/43388/volumes-and-issues. They also received individual Digital Object Identifiers (DOI), another frequent request from authors. All these, plus previous papers, are also free, as usual, at http://revbrasilornitol.com.br/BJO/ issue/archive.

The future, with lower workload for editors, a user-friendly platform for authors and reviewers, and professional paper production staff, makes us confident that authors, and the ornithological community as a whole, will be greatly benefited. More and better manuscripts are in the horizon. Ornithology Research will be particularly interested in sound studies with wild birds, both in the field and experimental ones; methodological studies, as well as reviews, highlighting gaps and theme synthesis, are particularly welcome. Authors and readers from other regions, but keeping a special view 


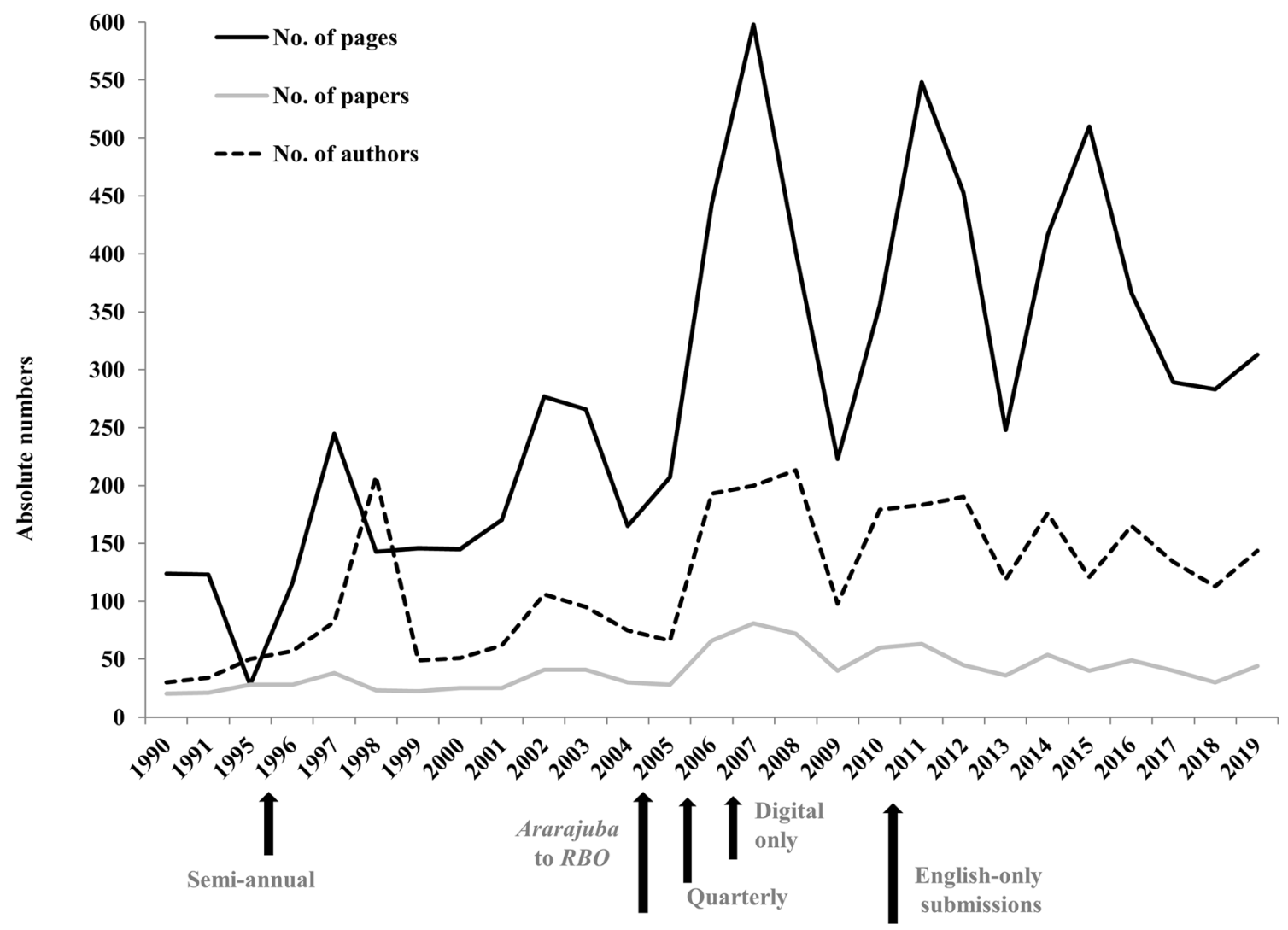

Fig. 1 Development of the ornithological journal published by the Brazilian Ornithological Society, early as Ararajuba and since 2005 as Revista Brasileira de Ornitologia (RBO). The absolute number of authors benefited, and papers (full papers, notes, book reviews, obituaries, and

over the Neotropical region, are expected to join us along the next years.

Acknowledgments The author is grateful to M.Â. Marini, L.F. Silveira, A.A. Aleixo, M.A.S. Alves, M.A. Pizo and M.B. Brandão for revision and suggestions on a previous draft.

\section{Compliance with ethical standards}

Conflict of interest The author declares that he has no conflict of interest.

Informed consent Not applicable.

\section{References}

Bornschein MR, Maurício GN, Belmonte-Lopes R, Mata H, Bonatto SL (2007) Diamantina Tapaculo, a new Scytalopus endemic to the Chapada Diamantina, northeastern Brazil (Passeriformes: Rhinocryptidae). Rev Bras Ornitol 15:151-174

Buzzetti DRC, Belmonte-Lopes R, Reinert BL, Silveira LF, Bornschein MR (2013) A new species of Formicivora Swainson, 1824 (Thamnophilidae) from the state of São Paulo, Brazil. Rev Bras Ornitol 21:269-291 commentaries) and pages published are shown. All papers are free to download at http://revbrasilornitol.com.br/BJO/issue/archive and from 2014 onwards at https://link.springer.com/journal/43388/volumes-andissues

Coelho G, Silva W (1998) A new species of Antilophia (Passeriformes: Pipridae) from Chapada do Araripe, Ceará, Brazil. Ararajuba 6:8184

Höfling E, Anjos L, Scherer-Neto P, Antas PTZ, Fontana CS (2017) Sociedade Brasileira de Ornitologia: a history. Rev Bras Ornitol 25:233-236. https://doi.org/10.1007/BF03544401

Mauricio GN (2005) Taxonomy of southern populations in the Scytalopus speluncae group, with description of a new species and remarks on the systematics and biogeography of the complex (Passeriformes: Rhinocryptidae). Ararajuba 13:7-28

Mazzar-Barnett J, Buzzetti DRC (2014) A new species of Cichlocolaptes Reichenbach 1853 (Furnariidae), the 'Gritador-do-nordeste', an undescribed trace of the fading bird life of northeastern Brazil. Rev Bras Ornitol 22:75-94. https://doi.org/10.1007/BF03544237

Silva JMC, Coelho G, Gonzaga LP (2002) Discovered on the brink of extinction: a new species of pygmy-owl (Strigidae: Glaucidium) from Atlantic Forest of northeastern Brazil. Ararajuba 10:123-130

Vielliard J (1990) Uma nova espécie de Asthenes da Serra do Cipó, Minas Gerais, Brasil. Ararajuba 1:121-122

Whitney BM, Vasconcelos MF, Silveira LF, Pacheco JF (2010) Scytalopus petrophilus (Rock Tapaculo): a new species from Minas Gerais, Brazil. Rev Bras Ornitol 18:73-88

Publisher's note Springer Nature remains neutral with regard to jurisdictional claims in published maps and institutional affiliations. 